\title{
Identification of Internet Usage and Dependency Level of Physical Education and Sport Teaching Students
}

\author{
Talha Murathan ${ }^{1}$ \\ ${ }^{1}$ School of Physical Education and Sports, Ardahan University, Ardahan, Turkey \\ Correspondence: Talha Murathan, Ardahan University, School of Physical Education and Sports, 75000, Ardahan, \\ Turkey. Tel: 505-656-5324. E-mail: talhamurathan@hotmail.com
}

Received: June 15, 2018

doi:10.5539/ies.v11n11p14
Accepted: July 25, $2018 \quad$ Online Published: October 22, 2018

URL: https://doi.org/10.5539/ies.v11n11p14

\begin{abstract}
The excessive internet usage that interrupts social relations, physical characteristics and mental conditions of individuals is called as internet addiction. At the previous studies, it is reported that university students are at risk of Internet addiction due to their uncontrolled lives without families and killing their time surfing the internet. The objective of this study is to identify the addiction level of university students' internet usage within the framework of some variables. A total of 463 students, 194 girls and 269 boys, who study at different 7 Departments of Physical Education and Sport Teaching within School of Physical Education and Sports and Faculties of Sport Sciences, attended this study in 2016-2017 Academic Years. "Personal Information Form" is used to determine the internet addiction of students "Internet Addiction Scale" developed by Young (1998) and to determine the demographic features and the data regarding the internet usage. In this study, the risk average for internet addiction of students is determined 2.55. It has been observed that the individuals who addict the internet constitute $3.9 \%$ of my samples. It is confirmed that internet addiction of male students is considerably higher than female students. It is ascertained that students who have Internet and a social media account are under higher risk of internet addiction. It has been emerged that there is no significant relation between the age/ monthly income of the family and the internet addiction level.
\end{abstract}

Keywords: internet addiction, student, spare time, university, physical education and sports

\section{Introduction}

In our present time, information and technology are in a period of rapid renewal. This renewal has also increased the use of internet (Tanriverdi, 2012). Since 1990s, the internet has been a rapid development process (Brian-Rotsztein, 2003). It has become easier for individuals to access the information they need; communication is easier; the needs in many areas such as education, banking bill payments, entertainment, shopping etc. can be easily fixed (Muslu \& Bolış1k, 2009). In 2017, it has been notified that the most intensive internet users are 16-24 aged males $66.8 \%(91.5 \%)$ and university graduates (97\%) use much internet than people (12.2\%) who do not graduate any school (Tuik, 2017).

Internet attracts much attention by the reason of being easily accessible network all over the world from different cultures and societies. That's why the internet can be utilized for various groups of ages and numerous purposes. The services provided by internet has increased in consequence of benefiting actively from computer technology while using internet and being cutting edge technology for computer and internet technology (Çakır, Horzum, \& Ayas, 2013). Furthermore, improvement of internet access speed with recent developments of technology and equipment diversity using for the access has caused significant increase at the user counts.

The development of internet and the growth of opportunities provided by internet day by day and also easily accessibility to internet have pushed individuals to use much internet. Individuals use intensively internet with the intent of some reasons such as communicate, reach the information, find friends, listen music, make payment and have fun (Bayraktutan, 2005). It is affirmed that individuals use most intensively (83.7\%) internet on the purpose of social media in Turkey (Tuik, 2017).

The concept of internet addiction is quite popular in the literature review of this issue. However, there are some debates whether the concept of internet addiction implicitly reflects negations caused by the internet (Ceyhan, 2011). In clinical applications, the concept of addiction divides basically into two categories as behavioural 
addiction and physical dependence. Behavioural addiction characterizes the activities including drugs and finding pathologic features of utilization associated with these substances, where as physical dependence describes generally the existence of tolerance and deprivation (Sevindik, 2011).

Conscious internet users regard the internet as an assistant tool; they use the internet for a certain purpose; they can separate their internet communications from their real-life communications and they do not behaviourally and cognitively experience any problem (Davis, 2001). Most part of the people use internet as needed. On the contrary, the other part of the people use internet more than enough; they cannot limit themselves and uncontrolledly kill their much time at the internet. In particular, there could be some problems at the school-age young such as psychological and somatic disorders, social relation defects and academic failures (Cengizhan, 2005). This circumstance could cause a disadvantage by becoming addiction (Karaman \& Kurtoğlu, 2009).

As a consequence of overusing the internet; psychological health disorders such as work overload feeling, stress, negative workplace environment; physical problems such as overusing the muscle strength, inappropriate bearing and non-stop working on the internet; environmental concerns such as noise, room temperature, humidity and lighting may be arisen (İnand1 \& Akyol, 2001). According to Young (1998), internet addiction is a control disorder by causing relational, professional and sociable problems in the lives of individuals without intoxicant substance. These individuals cannot prevent themselves from using internet; they denominate the time without internet as nonsense; they give negative reactions such as excessive irritability and aggression without having internet and their social and domestic relations break down (Young, 2004). Kandel (1998) reports that the psychologically-addicted individuals to Internet make ever-increasingly investment to internet sources in order to portray problematic behaviours and they are included in depression, aggression and deprivation when they do not use the internet. Kandel confirms that internet addiction is wide spread among the university student and this condition is derived from distantness of the students from their families and spending their free time at the internet without controlled by the families.

The objective of this study is to identify the internet usage addiction level of university students' who live in Turkey and study at the Departments of Physical Education and Sport Teaching.

\section{Method}

\subsection{Research Model}

In our study, survey research technique is used. Karasar (2013) defines survey research as a study approach that aims at describing past or at present situation with all faults. In this study adherent to literature review, the influence of variables such as gender, age, frequency of computer and internet usage to internet addiction on the students and the addiction levels in compliance with these variables are examined by defining the concept of internet addiction.

\subsection{Population and Sample}

Students in Sport Sciences Faculties, School of Physical Education and Sport and Physical Education and Sport Teaching within Faculty of Education constitute the population of the research. In the sample part of the study, there are 463 students (269 males, 194 females) who study in the Department of Physical Education and Sport Teaching at the universities from different geographical regions in the Second Term of 2016-2017 Academic Years. It has been elaborated that individuals who study different 7 regions of our country and have different economic, social and cultural conditions while selected samples.

\subsection{Data Collection}

In this study, "Internet Addiction Scale" developed by Young in 1998 and adapted into Turkish by Bayraktar (2001) and "Personal Information Form" developed by the researcher has been used in an attempt to identify the addiction levels of individuals. (In the personal information form, there are questions such as gender, age, monthly income, parental attitude, computer possession, the frequency and duration of internet usage, social media account etc.)

"Internet Addiction Scale" has been translated into Turkish. The reliability of the scale translated into Turkish has been found 0.91 in terms of standardized Alpha value and 0.87 with regards to Spearmen-Brown value. These results give rise to thought that this scale is reliable (Bayraktar, 2001). Cronbach alpha parameter is calculated as 90 for the reliability in this study.

\subsection{Analysis of Data}

SPSS 24.00 program is used for the analysis of data gathered in the research. On the purpose of having knowledge about the work group, descriptive statistics (percentage, frequency) for demographic information; independent 
groups' t-test, one-way analysis of variance (ANOVA) and Pearson correlation parameter technique for analysis of demographic information within internet addiction scale are used. Moreover, normality test has been implemented over data at the beginning of the statistical study.

\section{Results and Discussion}

The study has been fulfilled with 463 students who are studying at the Departments of Physical Education and Sport Teaching over 7 different universities from 7 different regions of Turkey. Demographic information about the students is shown at Table 1. While 194 participants of this study are female students (41.9\%), 269 participants $(58.1 \%)$ are male students. The most participants of the study are from Çukurova and Ardahan Universities (15.1\%), at least participants of the study are from Karadeniz Teknik University (KTÜ) (12.5\%). The ages of the participants differ from 18-32. In the study, age variable is divided into 4 different groups as 19 and below, 20-22, 23-25 and 26 and above. The highest age group participation to the study is 20-22 group (275 person); the lowest age group participation is 26 and above group ( 11 person). According to the scale of 4 th grading system, academic grade-point average of $18.8 \%$ of participants is between $3.00-4.00 ; 70.4 \%$ of participants is between $2.00-2.99$ and 10.8 participants have 1.99 and below academic grade-point average. When the monthly income is concerned, it is observed that the monthly income of families of 217 individuals is between $0-1500$ Turkish Liras (TL), the families of 160 is between 1501-2500 TL and the families of 86 participants is between 2501 and above. It is stated that the parents of $43.6 \%$ participants are democratic; $27.2 \%$ are authoritative; $24.2 \%$ are overprotective and $5 \%$ are careless. It is identified that $65.5 \%$ of participants have computer and $97.6 \%$ have internet access. To large extent participants (48.8\%) use internet 0-2 hour (s) in a day and 9.5\% use internet over 9 hours in a day. The large part of participants $(88.3 \%$ ) access internet via mobile phones and $72.6 \%$ of participants use internet so as to reach social media.

Table 1. Demographic information of participants

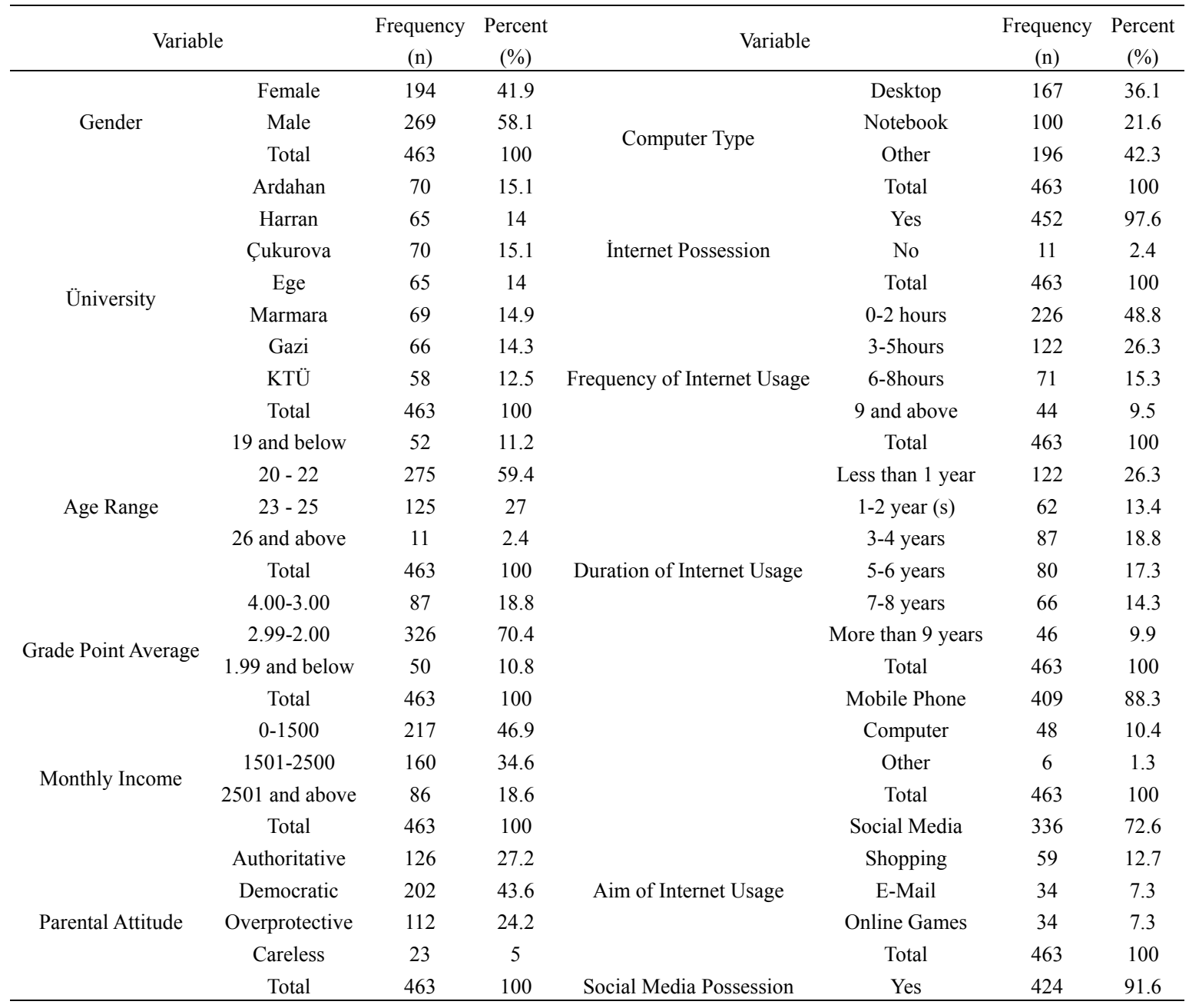




\begin{tabular}{lccccc}
\hline & Yes & 294 & 63.5 & No & 39 \\
Computer Possession & No & 169 & 36.5 & Total & 463 \\
& Total & 463 & 100 & 100 \\
\hline
\end{tabular}

It is obvious that $91.6 \%$ of the participants have a social media account, the percentage of Facebook users is 79.7 ; the percentage of Twitter users is 29.8; the percentage of Linkedin users is 1.3; the percentage of Instagram users is 59.2 and the percentage of MSN users is 23.5 (Table 2). Pempek et al. (2009) notified that the first reason for using Facebook for young individuals is to communicate with their friends. The other reasons are looking and sending photos, following the activities and entertainments. In our present time, social networks are intensively used by young generations. Glynn and et al. reported that 18-24 age range individuals use more social networks. It is known that university students in this age range group use intensively the social media.

Table 2. Usage rate of participants' social media accounts

\begin{tabular}{lcc}
\hline & Frequency $(\mathrm{n})$ & Percent $(\%)$ \\
\hline Facebook & 369 & 79.7 \\
Twitter & 138 & 29.8 \\
Linkedin & 6 & 1.3 \\
Instagram & 274 & 59.2 \\
Msn & 109 & 23.5 \\
Other & 21 & 4.5 \\
\hline
\end{tabular}

It is identified that risk average of the students are 2.55. It is determined that the level of internet addiction above 3.0 (critical level) is 104 participants $(22.5 \%)$ and internet addicts are 18 participants $(3.9 \%)$. In the previous studies with different groups, while some researches reach high rates, the others observe low rates. Aslan and Yazıc1 (2016) inform that the rate of internet addiction among university students is $2 \%$; the rate of students under the group of risk is $20.9 \%$ and the rate of normal internet users are $77.1 \%$. According to Bayraktar and Gün (2007), the rate of internet addiction among the students is 1.1\%. Canan et al. (2012) identified this rate as 9.7\%, Battgün and Hasta (2010) as 14\%; Dalbudak et al. (2013) as 7.2\%; Ak et al. (2013) as 5\%; Akdağ et al. (2014) $1.3 \%$; Bayraktar and Gün (2007) as 1\%; Niemz et al. (2005) as $18 \%$ and Young (1998) as $80 \%$. In his study, Alaçam (2012) revealed that the rate of internet addiction among university students is $0.6 \%$ and the rate of risky internet usage is $8 \%$. Batıgün and Hasta (2010) found this rate as $14 \%$. It maybe thought that the differences among the results are taken their source from socio-demographic distinctness of the research group, different scales and methodological diversity.

The level of internet addiction according to gender of participants is given in Table 3. Significant differences are identified in pursuant to gender. This difference is much meaningful among male students than females. In other words, the level of internet addiction level among male students is higher than female ones. The acquired this result overlaps with the previous results. Karaca (2017) proved that $26.8 \%$ of the students who study at a state university in İstanbul have internet addiction, $30 \%$ of this group are at risk having addiction potential and male students have much potential than female students. These kinds of results are pronounced by different researchers (Xu et al., 2012; Ak et al., 2013). Weiser (2000) uncovered that male student use internet further for fun and spending their free time. On the contrary, female students use internet for education and communication. It is specified that the use of online gambling, online games and pornography among men is higher than women which increases the rate of internet addiction (Liu et al., 2011). In their studies put into practice with the university students, Aslan and Yazıcı (2016) revealed that male students have risky internet usage than female students. Male lecturers use internet as leisure activity at higher rates when compared with female ones (Tel \& Köksalan, 2009). There are also some studies claiming that no significant difference about internet addiction between men and women (Aslan \& Yazıc1, 2016; Hills, 2003; Brenner, 2009; Batıgün \& Hasta, 2010). It is considered that these similarities and differences can be stemmed from cultural levelling and divergences of the countries. While men easily access the internet both home and places such as internet cafes, this situation is much restricted among women in the countries where women are much under pressure than men. 
Table 3. T-Testcomparison of students' internet addiction level according to their gender

\begin{tabular}{cccccc}
\hline Gender & $\mathrm{N}$ & Average & Std.deviation & $\mathrm{t}$ & $\mathrm{p}$ \\
\hline S_avg Woman & 194 & 2.28 & .74 & & \\
Man & 269 & 2.40 & .90 & -1.448 & .00 \\
\hline
\end{tabular}

$*(\mathrm{p}<0.05)$

In our study, the meaningful relation between age and internet addiction is not identified. It is notified that young individuals have higher internet addiction in the previous studies researched with different age groups (Wu et al., 2015; Morrison and Gore, 2010). There is no significant distinctness between age factor and internet addiction since the university students are selected as target group. Similarly, Aslan and Yazıc1 (2016) indicated that there is no important difference between age and internet addiction.

It is clear that there are differences in terms of the questions used in the scale about internet accessibility. As it is expected, this difference is much eloquent among the students having internet accessibility than the students who do not have (Table 4). It is obvious that the students with internet access are much dependent upon the internet than the students who do not have internet access.

Once more again, it has been manifested that there is no any statistically meaningful result between the families' monthly income and internet addiction level. In recent times, it is known that the devices which make easier to access the internet such as computer and mobile phone has increased. Every house has averagely one or more computers. Almost each student has a mobile phone to access internet. Students who have shoe-string budget also possess an internet tariff added to their mobile phones' invoices. There is free Wi-Fi in most places such as cafes and restaurants. In this respect, internet accessibility has become quite easier. In parallel with our results, Jackson et al. (2003) pointed out that internet usage was contingent upon monthly income of the families at past but there is no such situation in our current time.

Table 4. T-testcomparison of students' level average of internet addiction with the internet accessibility

$*(\mathrm{p}<0.05)$.

\begin{tabular}{cccccc}
\hline Internet Accessibility & $\mathrm{N}$ & Average & Std. Deviation & $\mathrm{t}$ & $\mathrm{p}$ \\
\hline S_avg Yes & 452 & 2.38 & .83 & & \\
No & 11 & 1.35 & .43 & & \\
\hline
\end{tabular}

Table 5. T-Test comparison of students' level average of internet addiction with the level of social media account possession

$*(p<0.05)$

\begin{tabular}{cccccc}
\hline Social Media & $\mathrm{N}$ & Average & Std. Deviation & $\mathrm{t}$ & $\mathrm{p}$ \\
\hline S_avg Yes & 424 & 2.38 & .85 & & \\
No & 39 & 2.01 & .66 & & \\
\hline
\end{tabular}

When Table 5 has been examined, it is understood that there is a significant difference at the level of internet addiction accordingly the social media usage of participants. The students who at have at least a social media account are much more dependent than the students who do not have social media account.

Table 6. Comparison of level average of internet addiction by participants' parental status with analysis of variance (Anova)

\begin{tabular}{ccccccc}
\hline & & K. Total & S.D & K. Avg. & F & P \\
\cline { 2 - 7 } & Intragroup & 19.811 & 3 & 6.604 & 9.800 & .000 \\
Intergroup & 309.292 & 459 & .674 & & \\
Total & 329.102 & 462 & & & \\
\hline
\end{tabular}


When the average of questions used in the scale has been compared with the parental attitudes of participants, it is observed that a significant difference attracts the attention. In consequence of Levene test in order to determine which group have this difference, it is monitored that there is important variation between authoritative parents, democratic parents, careless parents and overprotective ones (Table 6).

Table 7. Comparison of internet usage frequency and level average of internet addiction of participants with analysis of variance (Anova)

\begin{tabular}{ccccccc}
\hline & K. Total & S.D & K.Avg & F & P & Meaningful \\
\hline Intragroup & 12.679 & 3 & 4.226 & 6.131 & .000 & $6-8 / 0-2$ \\
Intergroup & 316.423 & 459 & .689 & & & \\
Total & 329.102 & 462 & & & & \\
\hline
\end{tabular}

$*(\mathrm{p}<0.05)$

In our current world, easily accessibility to internet causes individuals to spend their much time on the internet without control. This situation leads to internet addiction after a while. Internet addiction can cause some findings such as delay basic needs like sleep and food, imperceptions of elapsing, failure at school or home, lying, social isolation and exhaustion. In the cases where the internet accessibility is impossible, such symptoms as irritability, aggression and blasting may be observed (Young, 1998). Especially, this can induce psychological, sociological and physiological negations among adolescents (Tripodaki et al., 2008).

It is a well-known fact that students use much intensively the internet than the other groups on the purposes of both education and socialization. Therefore, students are considered as a risky group (Aslan \& Yazic1, 2016).

In the past, it was only possible to access the internet with computers but nowadays it is accessible with mobile phones, tablets, even watches. This condition increases the duration time on the internet. In our study, it is observed that there is an important difference between the frequency of internet usage and the level of internet addiction. The individuals who spend their 6-8 hours on the internet have higher level of internet addiction (Table 7). From the previous studies, it is understood that there is a positive relation between duration of internet usage and internet addiction (Eijnden et al., 2008; Yellowlees \& Marks, 2007; Batıün \& Hasta, 2010). Sirakaya and Seferoğlu (2013) remarks that the students who have increment at the frequency of internet usage probably indicate symptoms of internet addiction.

Table 8. Comparison of internet accessibility method and level average of internet addiction with analysis of variance (Anova)

\begin{tabular}{ccccccc}
\hline & K. Total & S.D & K.Avg & F & P & Meaningful \\
\hline Intragroup & 5.312 & 2 & 2.656 & 3.773 & .024 & Computer-mobile phone \\
Intergroup & 323.791 & 460 & .704 & & \\
Toplam & 329.102 & 462 & & & \\
\cline { 2 - 2 }$(\mathrm{p}<0.05)$ & & & &
\end{tabular}

An important difference between internet usage method and the rate of internet addiction has been identified in this study (Table 8). Carbonell et al. (2012) enounced that internet usage via mobile phone is frequent among women.

\section{Conclusion}

In this day and time, Internet is a tool which is used intensively for such fields as sharing information, research, and trade. It has become an inseparable part of daily life. Additionally, over and uncontrolled usage of internet is one of the most important issues in our era. The internet-addicted individuals cannot restrict themselves from the use of internet and they spend much their time on the internet without control. This circumstance causes psychological and physical problems especially among young people by weakening their social relations in a real-world. In our study conducted with the university students, we consider them under the highest risk group with regards to internet usage, it is identified that $3.9 \%$ of our samples are internet-addicted. It is proved that gender; internet accessibility, the internet access method and the duration of internet usage have an effect on the rate of addiction. It is determined that internet addiction does not have any meaningful difference considering alma mater university, age, grade-point average and income level. First and foremost, enhancement of actions that the students can 
participate needs to be increased. Furthermore, the students should be informed about internet addiction, the proper use of internet should be taught and the precautions for the limiting excessive usage should be carried out.

Consequentially, educational consciousness- raising movements oriented to well, reliable and controlled dissemination of the internet throughout the country should be existed.Internet can be arranged with service providers and experts. Academics that have an interest about this topic should encourage new studies within the scope of the variables embraced in this study. It is thought that new researches should be promoted about problematic internet usage especially at the primary education students and its prevention.

\section{References}

Ak, Ş., Koruklu, N., \& Yılmaz, Y. (2013). A study on Turkish adolescent's Internet use: possible predictors of internet addiction. Cyber psychology Behavior and Social Networking, 16(3), 205-209. https://doi.org/10.1089/cyber.2012.0255

Akdağ, M., Yılmaz, B. S., Ozhan, U., \& San, I., (2014). Investigation of University Students Internet Addiction in Terms of Several Variables (Inonu University Sample). Inonu University Journal of The Faculty of Education, 15(1), 73-96. https://doi.org/ 10.17679/iuefd.98972

Alaçam, H. (2012). Denizli Bölgesi Üniversite Öğrencilerinde İnternet Bağımlılı̆̆ının Görülme Siklı̆̆ ve Yetişkin Dikkat Eksikliği Hiperaktivite Bozukluğu ile Illişkisi. Pamukkale Üniversitesi Tıp Fakültesi, Uzmanlık Tezi.

Aslan, E., \& Yazıcı, A. (2016). Üniversite Öğrencilerinde İnternet Bağımlılı̆̆ı ve İlişkili Sosyodemografik Faktörler. Klinik Psikiyatri Dergisi, 19(3), 109-117. https://doi.org/10.5505/kpd. 2016.03511

Batıgün, A. D., \& Hasta, D. (2010). İnternet Bağımlılığı: Yalnızlık ve Kişilerarası İlişki Tarzları Açısından bir Değerlendirme. Anadolu Psikiyatri Dergisi, 11(3), 213-219.

Bayraktar F., \& Gün, Z. (2007). Incidence and correlates of internet usage among adolescents in north Cyprus. Cyberpsychology and Behavior, 10, 2-6. https://doi.org/10.1089/cpb.2006. 9969

Bayraktar, F. (2001). Internet Kullanımının Ergen Gelişimindeki Rolü. Yayınlanmamış Yüksek Lisans Tezi. Ege Üniveristesi. Sosyal Bilimler Enstitüsü. İzmir.

Bayraktutan, F. (2005). Aile İçi İlişkiler Açısından İnternet Kullanımı. Yayınlanmamış Yüksek Lisans Tezi. İstanbul Üniversitesi. Sosyal Bilimler Enstitüsü. İstanbul.

Brenner, V. (1996). An initial report on the online assessment of Internet addiction: The first 30 days of the Internet usage survey. Psychological Reports, 70, 179-210. https://doi. org/10.2466/pr0.1997.80.3.879

Brian-Rotsztein, M. A. (2003). Problem internet use and locus of control among college students: Preliminary findings, Lynch School of Education, Boston College, Poster Presented at The 35th Annual Conference of the New England Educational Research Organization Portsmouth, New Hampshire.

Çakır, Ö., Horzum, M. B., \& Ayas, T. (2013). İnternet Bağımlılığının Tanımı ve Tarihçesi. In M. Kalkan, \& C. Kaygusuz (Eds.), Internet Bağımlılı̆̆ Sorunlar ve Çözümler. Anı Yayıncılık: Ankara.

Canan, F., Ataoglu, A., Ozcetin, A., \& Icmeli, C. (2012). The association between internet addiction and dissociation among Turkish college students. Comprehensive psychiatry, 53(5), 422-426. https://doi.org/10.1016/j.comppsych.2011.08.006

Carbonell, X., Chamarro, A., Griffiths, M., Oberst, U., Cladellas, R., \& Talarn, A. (2012). Problematic Internet and cell phone use in Spanish teenagers and young students. Anales de Psicologia/Annals of Psychology, 28(3), 789-796. https://doi.org/10.6018/analesps.28.3. 156061

Cengizhan, C. (2005). Öğrencilerin Bilgisayar ve İnternet Kullanımında Yeni Bir Boyut: Bağımlılık. M. Ü. Atatürk Eğitim Fakültesi Eğitim Bilimleri Dergisi, 22, 83-98.

Ceyhan, A. A. (2011). Ergenlerin Problemli İnternet Kullanım Düzeylerinin Yordayıcıları. Çocuk ve Gençlik Ruh Să̆llğ $\mathrm{L}$ Dergisi, 18(2), 85-94.

Dalbudak, E., Evren, C., Aldemir, S., Coskun, K. S., Ugurlu, H., \& Yıldırım, F. G. (2013). Relationship of internet addiction severity with depression, anxiety, and alexithymia, temperament and character in university students. Cyberpsychology, Behavior and Social Networking, 16(4), 272-278. https://doi.org/10.1089/cyber.2012.03

Davis, R. A. (2001). A cognitive-behavioral model of pathological internet use. Computers in Human Behavior, 17, 187-195. https://doi.org/10.1016/S0747-5632(00)00041-8 
Eijnden, R, J., Meerkerk, G, J., Vermulst, A, A., Spijkerman, R., \& Engels, R. C. (2008). Online Communication, Compulsive Internet use and psychosocial well-being among adolescents: A longitudinal study. Dev Psychol, 44, 655-665. https://doi.org/10.1037/0012-1649.44.3.655

Glynn, C. J., Huge, M. E., \& Hoffman, L. H. (2012). All the news that's fit to post: A profile of news use on social networking sites. Computers in Human Behavior, 28, 113-119. https://doi.org/10.1016/j.chb.2011.08.017

Hills, P., \& Argyle, M., (2003). Uses of the internet and their relationship with individual differences in personality. Computers in Human Behavior, 19, 59-70. https://doi.org/10. 1016/S0747-5632(02)00016-X

İnandı, T., \& Akyol, İ. (2001). Bilgisayar kullanımı ile ilgili sağlık sorunları. Sürekli Tıp Eğitim Dergisi, Retrieved from http://www.ttb.org.tr/STED/sted0301/3.html

Jackson, L. A., Alexander, E., Biocca, F. A., Barbatsis, G., Fitzgerald, H. E., \& Zhao, Y. (2003). Personality, conitive style, demographic characteristics and internet use-findings from the home net too project. Swiss $J$ Psychol, 62, 79-90. http://dx.doi.org/10.1024//1421-0185.62.2.79

Kandell, J. J. (1998). Internet addiction on campus: The vulnerability of college students. CyberPsychology \& Behavior, 1, 11-17. https://doi.org/10.1089/cpb.1998.1.11

Karaca, F. (2017). Üniversite Öğrencilerinin İnternet Bağımlılığı İle Akıllı Telefon Kullanma Alışkanlıkları Arasındaki İlişkilerin İncelenmesi. Mehmet Akif Ersoy Üniversitesi Eğitim Fakültesi Dergisi, 44, 581-597. https://doi.org/10.21764/maeuefd.334953

Karaman, M. K., \& Kurtoğlu, M. (2009). Öğretmen Adaylarının İnternet Bă̆ımlıllğı Hakkındaki Görüşleri. XI. Akademik Bilişim Konferansı Bildirileri, Harran Üniversitesi, Şanlıurfa.

Karasar, N. (2013). Bilimsel Araştırma Yöntemi. Ankara: Nobel Yayıncılık.

Liu, T. C., Desai, R. A., Krishnan-Sarin, S., Cavallo D. A., \& Potenza M. N. (2011). Problematic Internet use and Health in Adolescents: Data from a High School Survey in Connecticut. The Journal of Clinical Psychiatry, 72(6), 836-845. https://doi.org/10.4088/JCP.10m06057

Morrison, C. M., \& Gore, H. (2010). The relationship between excessive internet use and depression: A questionnaire-based study of 1,319 young people and adults. Psychopathol, 43, 121-126. https://doi.org/10.1159/000277001

Muslu, G. K., \& Bolışı, B. (2009). Çocuk ve Gençlerde İnternet Kullanımı. TAF Preventive Medicine Bulletin, $8(5), 445-450$.

Niemz, K., Griffiths, M., \& Banyard, P. (2005). Prevalence of pathological internet use among university students and correlation swith self-esteem, the general health questionnaire (GHQ), and disinhibition. Cyberpsychol Behav, 8, 562-573. https://doi.org/10.1089/cpb. 2005.8.562

Pempek, T. A., Yermolayeva, Y. A., \& Calvert, S. L. (2009). College students' social networking experiences on facebook. Journal of Applied Developmental Psychology, 30(3), 227-238. https://doi.org/10.1016/j.appdev.2008.12.010

Sevindik, F. (2011). Fırat Üniversitesi Öğrencilerinde Problemli İnternet Kullanımı ve Sağlıklı Yaşam Biçimi Davranışlarının Belirlenmesi. Doktora Tezi, İnönü Üniversitesi Sağlık Bilimleri Enstitüsü, Malatya.

Sırakaya, M., \& Seferoğlu, S.S. (2013). Öğretmen Adaylarının Problemli İnternet Kullanımlarının İncelenmesi. Hacettepe Üniversitesi Ĕ̈itim Fakültesi Dergisi, 28(1), 356-368.

Tanrıverdi, S. (2012). Ortä̈gretim Öğrencilerinde İnternet Bă̆ımlıllğg ile Algılanan Sosyal Destek Arasındaki İlişkinin İncelenmesi. Yayınlanmış Yüksek Lisans Tezi. Van: YYÜ. Eğitim Bilimleri Enstitüsü.

Tel, M., \& Köksalan, B. (2009). Günümüzde Yeni Bir Boş Zaman Aktivitesi Olarak İnternet: Öğretim Üyeleri Örneği. Elektronik Sosyal Bilimler Dergisi, 8(28), 262-272.

Tripodaki, E., Kormas, G., Konstantoulaki, E., Andrie, E., Nassis, G., \& Freskou, A. (2008). Internet use and abuse in an Adolecent Population in Athens: Associations With Psychological Profile and Lifestyle of Users. Official Journal of the American Academy of Pediatrics, 121, 89-90. https://doi.org/10.1542/peds.2007-2022D

Tuik. (2017). Retrived from http://www.tuik.gov.tr/HbPrint.do?id=24862

Weiser, E. B. (2000). Gender Differences in Internet Use Patterns and Internet Application Preferences: A Two-sample Comparison. Cyber Psychology \& Behavior, 3(2), 167-178. 
https://doi.org/10.1089/109493100316012

Wu, C. Y., Lee, M. B., Liao, S. C., \& Chang, L. R. (2015). Risk Factors of Internet Addiction among Internet Users: An Online Questionnaire Survey. PloS One, 10, 1-10. https://doi.org/10.1371/journal.pone.0137506

Xu, J., Shen, L. X., Yan, C. H., Hu, H., Yang, F., Wang, L., ... Marks, S. (2007). Problematic internet use or internet addiction? Computers in Human Behavior, 23, 1447-1453. https://doi.org/10.1016/j.chb.2005.05.004

Young, K. S. (1998). Internet addiction: The Emergence of a New Clinical Disorder. Cyberpsychol Behavior, 1(3), 237-244. https://doi.org/10.1089/cpb.1998.1.237

Young, K. S. (2004). Internet addiction: A new clinical phenomenon and its consequences. American Behavioral Scientist, 48(4), 402-415. https://doi.org/10.1177/0002764204270278

\section{Copyrights}

Copyright for this article is retained by the author(s), with first publication rights granted to the journal.

This is an open-access article distributed under the terms and conditions of the Creative Commons Attribution license (http://creativecommons.org/licenses/by/4.0/). 